\title{
A CONCEPTUAL MODEL OF INTENTION TO USE ONLINE COLLABORATIVE CONSUMPTION PLATFORM
}

\author{
Lukni Burhanuddin Ahmad*1 and Reza Ashari Nasution*) \\ *) School of Business and Management, Institut Teknologi Bandung \\ Jl. Ganesha No.10, Lebak Siliwangi, Coblong, Bandung 40132
}

\begin{abstract}
The objective of this study is trying to develop a comprehensive model referring to previous research of Hwang and Griffith's model of intention to participate in Collaborative Consumption (CC). The study applied exploratory research design which implements previous researches regarding online collaborative consumption focusing on a study by Hwang and Griffith. Hwang and Griffith's model of intention to participate in Collaborative Consumption (CC) is unique in that it recognizes both attitudes and sympathy as the primary predictors of the intention to use the $\mathrm{CC}$ platform. The model is also relevant to $\mathrm{CC}$ as it encompasses different values, which are utilitarian, hedonic and symbolic. This Study results in a comprehensive model which incorporating several variables from previous studies, such as online initial trusts and perceived behavioral control. We conclude that by trying to put Technology Acceptance Model (TAM) and The Unified Theory of Acceptance and Use of Technology (UTAUT) will enrich the global-scale model from the higher point of view besides the cognitive perception itself. Moreover, this conceptual model is developed as a suggestion for future research as well as the implementation of more sophisticated statistical analysis method should be included.
\end{abstract}

Keywords: digital business; startup; user intention; online market; collaborative consumption

\begin{abstract}
Abstrak: Tujuan dari penelitian ini adalah mencoba mengembangkan model secara komprehensif yang mengacu pada penelitian sebelumnya dari model Hwang dan Griffith dalam niat untuk berpartisipasi platform Collaborative Consumption (CC). Studi ini menerapkan desain penelitian eksploratifyang mengimplementasikan penelitian sebelumnya tentang konsumsi kolaboratif online yang berfokus pada studi oleh Hwang dan Griffith. Hal tersebut menarik karena menempatkan attitude dan empati sebagai prediktor utama niat untuk menggunakan platform CC. Model ini juga relevan dengan CC karena mencakup nilai yang berbeda, yang utilitarian, hedonis, dan simbolis. Studi ini menghasilkan model komprehensifyang menggabungkan beberapa variabel dari penelitian sebelumnya, seperti online initial trust dan perceived behavioural control. Kami menyimpulkan bahwa dengan mencoba menempatkan Technology Acceptance Model (TAM) dan The Unified Theory of Acceptance and Use of Technology (UTAUT) akan memperkaya model skala global dari sudut pandang yang lebih tinggi selain persepsi kognitif itu sendiri. Selain itu, model konseptual ini dikembangkan sebagai saran untuk penelitian dimasa yang akan datang serta penerapan metode analisis statistik yang lebih akurat harus dimasukkan.
\end{abstract}

Kata kunci: bisnis online, startup, niat pengguna, pasar online, collaborative consumption

\footnotetext{
${ }^{1}$ Corresponding author:

Email: lukni_burhanuddin@sbm-itb.ac.id
} 


\section{INTRODUCTION}

The phenomenon of digital business is quickly and perpetually developed in recent years. The Millenial users are offered various product and innovative features that give us ease through the digital channel. According to Hwang and Grififths (2016), Millenials are also considered as the most appealing market (2016). The business itself is formed into several types of function which is commonly used for selling-buying, renting, until offering a service through a marketplace kind of platform. According to Piscielly et al. (2015), Those such of business is created as a sharing business known as collaborative consumption platform which represented as a socio-economic model enforced with technology in which groups share the utilisation of the product or service by the economic burden of ownership. Because of the evolution of business revolution 4.0, dissemination of social networks served the idea for peer-to-peer communication through platform also as direct transactions between customers and producers (Gansky, 2011).

Maximizing the utilization of products by sharing its usage and charging a fee for the user, depending on the product offered is a common purpose and business goal of CC platform, as mentioned above. Moreover, CC can connect among parties to perform their own business through a digital platform (Gansky, 2011). Initially, the objective of collaborative consumption was to share the financial burden of ownership (Piscicelli et al. 2015), but nowadays, it has developed to serve different kinds of both social and economic motivations. This scenario, then, provides two benefits that come up for this continuous movement, i.e. reduced costs and better-perceived quality by consumers as they use online platforms (Botsman, 2015).

If we refer to the publication concerning conceptual Model of Collaborative Consumption (CC) projected by Hwang and Griffiths (2016), his study has been explored on the early stage, but there are still many spaces to fill the gap on the CC theory. The challenge is to focus on how to communicate with users to raise consumer's positive perceptions as well as the behavioural intention to use the service which has been given. Additionally, by communicating Utilitarian and hedonic value that is tailored with Symbolic benefit related to collaborative Consumption (e.g. society and environmental impact) to increase sympathy can intercommunicate in order to encourage consumer's intention.

However, the conceptual model still needs several adjustments where online initial trusts and perceived behavioural control are two essential factors to be considered to include in the whole construct regarding collaborative consumption. If we refer to the research conducted by Thamizhvanan and Xavier (2013), Kim and Ahn (2007), Chen and Barnes (2007), Sun (2010), Pavlou and Gefen (2004), Hsu et al. (2014), Shadkam (2012), Becerra and Korgaonkar (2011), Kim JB (2012), and Schlaegel (2015) has a similar suggestion to put the this two construct to the model to complete the missing factor. Perceived behavioural control is also mentioned in several papers regarding digital platform such as Cheah et al. (2015) and Dakduk et al. (2017) which is interesting to be concluded into this study.

Furthermore, Hwang and Griffiths's model is depicting of how the cognitive perception and affective attitude of users inline with the behavioural intention in participating $\mathrm{CC}$ as well as the relationship of its moderating variable, even though they bound their sample to millennial consumers using 4 major categories (gadget, clothing, transportation, and labour sharing). Moreover, the needs to focus in broad view of the technological model is essential to be implemented to complete the overall factors of users to use online collaborative consumption because of the digital platform as a branch of applicable technology. The additional variables from the Technological Acceptance Model (TAM) and The Unified Theory of Acceptance and Use of Technology (UTAUT) will enrich the globalscale model from the higher point of view besides the cognitive perception itself.

In the model also, they put empathy as an essential factor influencing the intention to use CC. Empathy is a prosocial behaviour which stems from a participant who attaches with other individual's feelings (Eissenberg And Miller, 1987). Further studies explore the variable of empathy in someone's motivation context to help others (selfless action) who need based on the ability to stick to other's perspective (Veloutsou, 2012). Escalas and Stern (2003) experimented with ad response, and they also demonstrated that consumer's empathy had affected the customer's attitude towards advertisement in terms of prosocial behaviour. 


\section{METHODS}

In the methodology of this article, we apply literature review research started to form, which implements previous studies regarding online collaborative consumption starting in august 2017 till January 2019. There is about 30 literature we have collected regarding collaborative consumption from various context. The highlight of this research is to enrich Hwang and Griffith's model of intention to participate in Collaborative Consumption (CC) with two another theory regarding technology which is Technology Acceptance Model (TAM) and The Unified Theory of Acceptance and Use of Technology (UTAUT). The aim of this conceptual research is based on the shortcoming available research on this topic before it is tested with empirical research.

Air $\mathrm{BnB}$, is an example of Collaborative Consumption which has a sharing feature in the online community that specify to the renting houses (Garret et al. 2017). Likewise, Haridh (2018) describe the two most common investment that someone makes are usually to property like home and automotive. The owner usually does not seem to use it entirely while the homes or cars are idled most of the time. Through digital technology, those became more economical as well as can maximise the utilisation of the product itself. The website/apps which have been successfully providing that feature are Uber (US\$48 billion), Gojek (US\$3 billion), Grab (US\$6 billion), Airbnb (US\$31 billion).

Defining the online collaborative consumption in this paper refers to the emphasizing of two-way communication among peer through an online platform to function or maximize the product utilization by sharing or renting with the fee that might be charged.

There are many studies to identify motivation concerning Collaborative Consumption, Attitudes, and Behavioral Intentions (Johnson et al. 2016). There are four motives according to Nelson et al. (2007) when a person wants to participate for sharing with others, they are decluttering, economic factor (e.g. saving money, obtaining bargains), environmental focus, and interest to help others/desire for social value. Another study conducted by Lamberton and Rose (2012), Collaborative Consumption was directly correlated with the probability that a product might be unavailable at the moment. When the participant believes the item they were looking for would be unavailable, the higher participation's level of interest in CC will arise. Moreover, Belk (2014) wrote about CC that several items motivate a person who are likely to participate in collaborative consumption. Car, for example, it has become cost exorbitant and for some customer like a teenager, did not see these items as part of selfdefinitions. So in this research, we propose the model in CC, which is depicted as in Figure 1.

\section{RESULT}

\section{Attitude Towards Collaborative Consumption}

Hamari et al. (2013) link motives attitudes to behaviours in the Collaborative Consumption context in his study. In the research of $\mathrm{CC}$ focusing on apparel like the study conducted by Johnson et al. (2016), the result showed it has a robust significant relation between attitudes and intention to participate in CC. According to TAM which widely adopted by the researchers to explain the intentions of each user and the actual behaviours on the specific technology (Khare and Sadachar, 2014), consumers' intention to use a particular technology is influenced by the consumers' attitude toward that technology. It is proved by much previous research that shows there is a connection between attitude and intention, in this study is also put attitude as a variable when the user evaluate overall aspect before they are intended to use the $\mathrm{CC}$ platform.

\section{Perceived Behavioural Control}

The Unified Theory of Acceptance and Use of Technology (UTAUT) (Venkatesh et al. 2003) puts Perceived Behavioural Control (PBC) as a construct indicating personal's trigger to act on the intention to the behaviour. Borrowing from The Theory of Planned Behavior, $\mathrm{PBC}$ was defined by UTAUT as an individual's perceived ease or difficulty to perform the particular behaviour. It is considered that perceived behavioural control might be determined by the accumulation set of attainable control beliefs. In short, PBC explains how easy or difficult user can perform behavioural intention. In this digital $\mathrm{CC}$ context, the existence of perceived behavioural control construct can add some variables which complete the model from the side of the user's control when using a computer-based platform. 


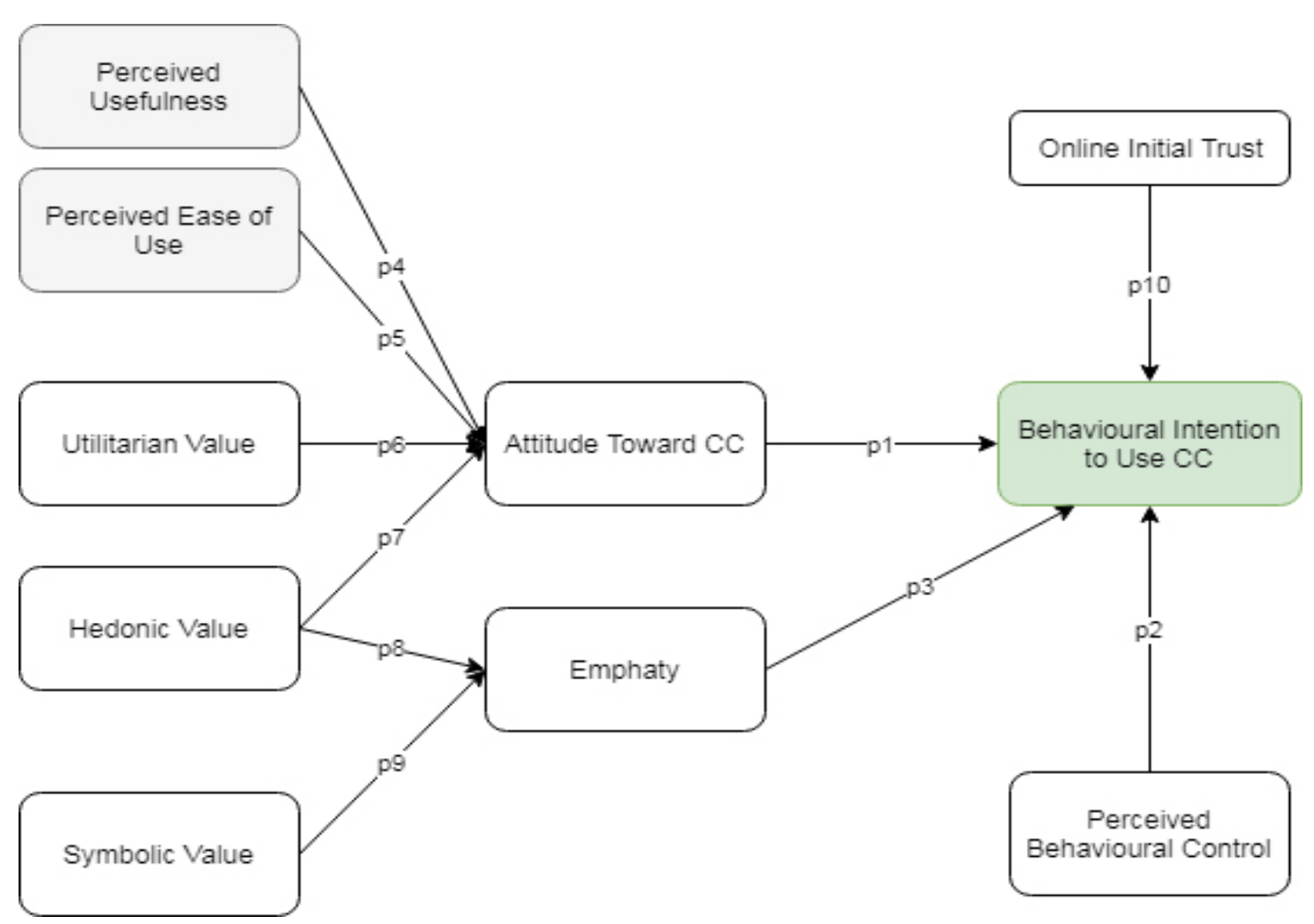

Description: P1 (Attitude toward the online CC positively relates with behavioural intention to collaboratively consumption through an online platform); P2 (Perceived Behavioural Control positively influence the behavioral intention to collaboratively consumption through an online platform); P3 (Empathy influence the behavioral intention to collaboratively consumption through an online platform); $\mathrm{P} 4$ (Perceived Ease of Use has a positive influence on the Attitude toward collaborative consumption through an online platform);P5 (Perceived Usefulness has a positive influence on the Attitude toward collaborative consumption through an online platform); P6 (Utilitarian Value positively influence the Attitude toward collaborative consumption through an online platform); P7 (Hedonic Value positively influence the Attitude toward collaborative consumption through an online platform); P8 (Hedonic Value has a positive influence on Empathy toward collaborative consumption through an online platform); P9 (Symbolic Value has a positive influence on the Empathy toward collaborative consumption through an online platform); P10 (Online initial trust positively influences the behavioral intention to collaborative consumption through an online platform).

Figure 1. Conceptual model of intention to use cc

Ajzen (1985) in his research of Theory of Planned Behaviour put Perceived Behavioural Control as a variable indicating personal's trigger to act on the intention to the behaviour. He writes PBC as a person's perceived ease or difficulty to conduct particular behavior. Perceived behavioral control is considered might be determined by the accumulation set of accessible control beliefs. It is reflected as the beliefs about the presence of variable that could facilitate or impede performance in behavioural action. When the perceived behavioural control is higher, so it means more probability that the behaviour will occur (Chien et al. 2014). Prihantoro et al. (2018), in their study, confirms the existence of $\mathrm{PBC}$ as the factor in the intention towards e-commerce application. Considering this Perceived Behavioural Control lying on the using intention of the digital product is make sense because the needs of computer skill to use it so the digital natives will have a higher degree to use $\mathrm{CC}$ comparing to those who are starting to use an online platform like a digital migrant. Not only from the capability of using the platform, but the need for resource to attain the accessibility to use $\mathrm{CC}$ is also important. This case can be correlated with the type of gadget when the users online or how the connectivity can support when using the digital platform.

\section{Empathy}

In the model proposed by Hwang et al. (2016) with the same context in CC, they put empathy as one crucial factor influencing intention to use CC. By definition, 
Empathy referring to Eissenberg (1978) is a prosocial behaviour which stem from a participant who inclose with other individual's feelings Other studies explore empathy in a person motivation context to help the fellow (altruistic action) who needs based on the ability to see from other's perspective (Veloutsou, 2012). According to Escalas and Stern (2003), empathy also has its multidimensional construct. Another perspective besides the individual feeling attachment, empathy might refer to an outcome of perceptual practices or cognitive (Eisenberg NW, 1998) and also feeling sympathy, concern, and compassion (Batson, 1991). The various perception of empathy's position is also served as more concrete items into two, emotional empathy and cognitive empathy (Parra, 2013). Emotional empathy is more into vicariously distribute the emotion while cognitive empathy is considered the capability to adopt the perspective of others. In Hwang and Griffiths's study, they incorporate empathy as to understand how consumer intent to use, buy or rent the collaborative consumption's services/product served by the companies from the emotional aspect. In this study. Empathy on this research is proposed as the user's emotional feeling to attach with other users through the platform, which releases feeling concern to it.

\section{Perceived Ease of Use and Perceived Usefulness}

Yu-Bin et al. (2005) describe confirm the significance from perceived ease of use and perceived usefulness to intention to purchase a product from CC. Davis et al. (1985) proposed that perceived usefulness is a highly significant variable of attitudes to apply the new technology at two different periods in the word processing software context. Strengthen the theoretical foundation, other similar studies researched by Venkatesh and Davis (1996), Mathieson (1991), Szajna (1996). Agarwal and Karahanna (2000) Adams et al. (1992), which also support the idea. The modification of TAM to use in the context of Information Technology is also proofed (Yu-Bin et al. 2005). According to ChingWen and Hsi-Peng (2007) in the research which is related to digital music platform, perceived usefulness has a meaning of the level to which extent the users believes that listening to the music can accomplish several purposes. Connecting the line with collaborative Consumption Context, using CC platform might fulfil the user's purpose of collaboration.
Moreover, Perceived ease of use refers to TAM proposed by Davis (1985) is correlated with individual's belief that the technology used will provide an effortless experience and will directly or indirectly affect to the intention to use. Another study proposed by Hsieh et al. (2008) found that perceived ease of use has a significant influence to lead continuance the use of technology. In this research, perceived ease of use will relate to the user's comfortability and effortless usage.

Utilitarian Value, Hedonic Value, and Symbolic Value Motivational to purchase is divided into two different perspectives according to Blackwell (2006), in his theory, intrinsic and extrinsic. Intrinsic motivation such as utilitarian and hedonic value is considered to exist from the judgment by the person of the benefits after consumption experience (Wang, 2007). The extrinsic factor-like privacy and security, which is appropriate with the influence of external resources, this study will specify to intrinsic perspective only. Another idea from Kim and Han (2011) described that Hedonic Value was obtained from consumers feeling. It is more personal that derived as a pleasant feeling than task accomplishing. It reflected more as entertainment and emotional during shopping rather than the purpose like in utilitarian Value. Giving an example when the person who reflects Hedonic Value will probably seek more into the pleasure of shopping rather than the urgency to buy necessary goods for utilitarian Value. Therefore this research will be correlated if we put these two intrinsic variables, Utilitarian and Hedonic Value. Meanwhile, Symbolic Value is correlated with social value or altruistic that means the awareness of sustainability to consume. For example, when the consumer uses a product, it will be possible to reduce the carbon footprint.

\section{Online Initial Trust}

Yoon (2012) described Trust in the digital platform context functioning as a mechanism which is categorized into three, technical-based perspective, the uncertainty of transaction, and competency-based reputation. Technical based is related to the technical aspect in the online platform and how the users can receive from it such as web searching, the website or apps presentation, and of course, the technology itself. The uncertainty of transaction and security is more correlated with how the digital platform can assure security. The competencybased perspective will tightly relate to how impactful the brand reputation of the application, interaction, 
as well as fulfilment. Individual researchers such as Mayer et al. (1995) define trust is a set of distinct beliefs, including ability, integrity, and benevolence. It is a willingness of one individual to be indefensible to others behaviour. Moreover, Rempel et al. (1985) stated that trust is a feeling of confidence as well as security that responds to other parties

According to Hwang and Griffith's (2016) findings, valueperception of collaborative consumption userplays a vital role in their attitudes and empathy. The findings show the complexities of the different dimensions of value perception as well as the overall supporting evidence of value-attitude-intention correlation concerning collective consumption. From the final conceptual model they found, important constructs are becoming a foundation in this study. To complete and enrich the model with basic technological theory, we place variables from two theories that complete each other; they are TAM and UTAUT.

Intention to use $\mathrm{CC}$ can be identified as a willingness of users to use the CC platform. Consumers' use intention is a vital factor to measure and determine the consumers' online behaviour to use a product, as well as to become an indicator for market penetration when a startup launches a new product. According to TAM, consumers' intention to use a particular technology is influenced by the consumers' attitude toward that technology. Consumers like to use new technology when they believe that the product will increase their work performance. Two variables borrowed from TAM have perceived usefulness and perceived ease of use.

UTAUT defines PBC as an individual's perceived ease or difficulty to perform a particular behaviour. It is considered that perceived behavioural control might be determined by the accumulation set of attainable control beliefs., PBC explains how easy or difficult user can perform behavioural intention. Control beliefs are reflected as the beliefs about the presence of an element that might facilitate or preclude performance in behavioural action. It is likely when the higher the perceived behavioural control is, the more probability the behaviour will occur [18]. According to Mathieson et al. [50], the perceived behavioural control deals with the individual who feels that the control is within his or her power.

As mentioned above, Empathy on this study is the consumer's emotional feeling to attach with another user through the digital platform that releases feeling concern to it. According to Keeble (2013), collaborative consumption might induce value perceptions (utilitarian, hedonic, and symbolic value). Utilitarian value exists when the platform offers more benefit of sharing usage with other than ownership. For instance, Go-Jek provides ride-sharing with either bike or car which bring more advantages than we have to buy it. Differently, the hedonic value can rise when the platform of collaborative consumption bring experience to entertain the users (Babin and Attaway, 2000). One example of how this construct existed is when Gojek not only provides a helpful experience with food delivery service but also gives fun and exciting way to choose various menus through a smartphone which lured with enormous discount. Different from those two, symbolic value appeared when the collaborative consumption platform brought positive outcomes as part of the prosocial movement. For example, by using sharing transportation or environmentally friendly product or service can indicate the existence of individual prosociality or in this case, a signalling effect of good deeds of symbolic value (Bird and Smith, 2005).

According to Holbrook (1994), empathy is influenced by the consumer's value perception, which considered having a significant effect on marketing activities. Yet, Hwang and Griffiths's result shows that symbolic value increases empathy, but not attitude and utilitarian value increases attitude but not empathy, The effect of value on empathy alongside with attitude suggests that increasing awareness of prosocial issues translates into empathetic feelings about collaborative consumption (Botsman and Rogers, 2010; Prothero et al. 2011). Hence, we propose this conceptual model as a findings of our qualitative approach of literature review from various research in relation with digital collaborative consumption.

\section{Managerial Implication}

On the business organization implementation, the result of this research may help the product manager or startup owner in order to redesign its product, becoming more valuable assets that can generate more users. They should create a user-friendly product which accommodates those variables to enhance the intention of the user to use the platform. However, this study is still limited to the conceptual model only that is conceived through the past literature. Nevertheless, the model at least can be implemented for the managerial position, 
such as product development or user experience to maximise the user intention on the platform, which can benefit the business itself.

\section{CONCLUSIONS AND RECOMMENDATIONS}

\section{Conclusions}

As stated above, The phenomenon of Silicon Valley's product capitalization in the world digital technology lifestyle has been influencing the startup scheme globally in various countries. This study is an extended model which is developed by previous research to specify on the user intention in a collaborative consumption specific context becoming more general with some the additional variables from the theory of Technology Acceptance Model. We consider The TAM model can give a significant effect on the digital CC platform intention due to the channel is a part of the current technology. The model also put some variables that influence collaborative consumption in an offline way, such as empathy and the values from Hwang's proposal.

\section{Recommendations}

This study also suggests further research of digital collaborative consumption platform, which is previously proposed by Hwang and Grifiths (2010). This study, however, is not focusing on the digital platform as it explains in specific context only (fashion, labour/expertise, tech gadgets and bike-sharing) but more into a generic domain. Regarding the definition in this research, in another context such as health industry, communication, and other distinct industries in the digital platform can also develop the essential characters of CC such as peer-to-peer communication, utilising the use to the economic factor by its user and also maximising the sharing process by its use. This research is conducted to fill the lack of research in which the technology acceptance model become a foundation of the internet user to use technology. This result can also contribute to the previous study by Hwang and Griffiths (2016), which add other three variables, and they are perceived ease of use, perceived usefulness and perceived behavioural control. However, this model has not been tested on empirical research so that it can be a good start for future research to prove this idea.

\section{REFERENCES}

Ajzen I. 1985. From Intentions to Actions: A Theory of Planned Behavior. Berlin: Springer. https://doi. org/10.1007/978-3-642-69746-3_2.

Babin BJ, Attaway JS. 2000. Atmospheric effect as a tool for creating value and gaining share of customer. Journal of Business Research 49(2): 91-99. https://doi.org/10.1016/S01482963(99)00011-9.

Batson CD. 2014. The Altruism Question Toward A Social-psychological Answer. New York: Psychology Press. https://doi. org/10.4324/9781315808048.

Becerra EP, Korgaonkar PK. 2011. Effects of trust beliefs on consumers' online intentions. European Journal of Marketing 45(6): 936-962. https:// doi.org/10.1108/03090561111119921.

Belk R. 2014. You are what you can access: sharing and collaborative consumption online. Journal of Business Research 67(8): 1595-1600. https:// doi.org/10.1016/j.jbusres.2013.10.001.

Bird RB, Smith EA. 2005, Signaling theory, strategic interaction, and symbolic capital. Current Anthropology 46(2):221-248. https://doi. org/10.1086/427115.

Blackwell RM. 2006. Consumer motivation. Consumer Behavior, 289-328.

Botsman R. 2015. Defining the sharing economy: what is collaborative consumption-and what isn't.

Botsman R, Rogers R. 2011. What's Mine Is Yours. London: HarperCollins Business.

Cheah I, Phau I, Liang J. 2015. Factors influencing consumers' attitudes and purchase intentions of e-deals. Marketing Intelligence \& Planning 33(5):763-783. https://doi.org/10.1108/MIP-052014-0081.

Chien SP, Wu HK, Hsu YS. 2014. An investigation of teachers' beliefs and their use of technologybased assessments. Computers in Human Behavior 31:198-210. https://doi.org/10.1016/j. chb.2013.10.037.

Chu CW, Lu HP. 2007. Factors influencing online music purchase intention in Taiwan. Internet Research 17(2):139-155. https://doi. org/10.1108/10662240710737004.

Dakduk S, Ter Horst E, Santalla Z, Molina G, Malavé J. 2017. Customer behavior in electronic commerce: a Bayesian approach. Journal of Theoretical and Applied Electronic Commerce Research 12(2):1-20. https://doi.org/10.4067/ 


\section{S0718-18762017000200002.}

Davis FD. 1985. A technology acceptance model for empirically testing new end-user information systems: Theory and results [dissertation]. Boston: Massachusetts Institute of Technology.

Eisenberg N, Miller PA. 1987. The relation of empathy to prosocial and related behaviors. Psychological Bulletin 101(1):91.https://doi.org/10.1037/00332909.101.1.91.

Escalas JE, Stern BB. 2003. Sympathy and empathy: Emotional responses to advertising dramas. Journal of Consumer Research 29(4): 566-578. https://doi.org/10.1086/346251.

Gansky L. 2010. The Mesh: Why the Future of Business is Sharing. Penguin.

Hamari J, Sjöklint M, Ukkonen A. 2016. The sharing economy: Why people participate in collaborative consumption. Journal of the Association for Information Science and Technology 67(9):20472059. https://doi.org/10.1002/asi.23552.

Haridh A. 2018. Who bears the credit risk in a sharing economy? Singapore: The Business Times.

Holbrook MB. 1994. The nature of customer value: an axiology of services in the consumption experience, in Rust, R.T. and Oliver, R.L. (Eds), Service Quality: New Directions in Theory and Practice, Thousand Oaks: Sage. https://doi. org/10.4135/9781452229102.n2.

Hsu MH, Chuang LW, Hsu CS. 2014. Understanding online shopping intention: the roles of four types of trust and their antecedents. Internet Research 24(3): 332-352. https://doi.org/10.1108/IntR01-2013-0007.

Hsieh JPA, Rai A, Keil M. 2008. Understanding digital inequality: Comparing continued use behavioral models of the socio-economically advantaged and disadvantaged. MIS quarterly 32(1): 97-126. https://doi.org/10.2307/25148830.

Hwang J, Griffiths MA. 2016. Share more, drive less: Millennials value perception and behavioral intent in using collaborative consumption services. The Journal of Consumer Marketing 34/2(2017): 132-146 https://doi.org/10.1108/ JCM-10-2015-1560.

Johnson KK, Mun JM, Chae Y. 2016. Antecedents to internet use to collaboratively consume apparel. Journal of Fashion Marketing and Management 20(4): 370-382. https://doi.org/10.1108/JFMM12-2015-0092.

Keeble J. 2013. Young consumers hold the key to sustainable brands, available at: www. theguardian.com/ sustainable-business/youngconsumers-key-sustainablebrands (accessed 13 July 2013).

Khare A, Sadachar A. 2014. Collective self-esteem and online shopping attitudes among college students: Comparison between the US and India. Journal of International Consumer Marketing 26(2): 106-121. https://doi.org/10.1080/089615 30.2014 .878203 .

Kim B, Han I. 2011. The role of utilitarian and hedonic values and their antecedents in a mobile data service environment. Expert Systems with Applications 38(3): 2311-2318. https://doi. org/10.1016/j.eswa.2010.08.019.

Kim JB. 2012. An empirical study on consumer first purchase intention in online shopping: integrating initial trust and TAM. Electronic Commerce Research 12(2): 125-150. https://doi. org/10.1007/s10660-012-9089-5.

Lamberton CP, Rose RL. 2012. When is ours better than mine? A framework for understanding and altering participation in commercial sharing systems. Journal of Marketing 76(4): 109-125. https://doi.org/10.1509/jm.10.0368.

Mayer RC, Davis JH, Schoorman FD. 1995. An integrative model of organizational trust. Academyof Management Review 20(3): 709-734. https://doi.org/10.5465/amr.1995.9508080335.

Nelson MR, Rademacher MA, Paek HJ. 2007. Downshifting consumer $=$ upshifting citizen? An examination of a local freecycle community. The Annals of the American Academy of Political and Social Science 611(1): 141-156. https://doi. org/10.1177/0002716206298727.

Parra A. 2013. Cognitive and emotional empathy in relation to five paranormal/anomalous experiences. North American Journal of Psychology 15(3): 405-412.

Piscicelli L, Cooper T, Fisher T. 2015. The role of values in collaborative consumption: insights from a product-service system for lending and borrowing in the UK. Journal of Cleaner Production 97: 21-29. https://doi.org/10.1016/j. jclepro.2014.07.032.

Prihantoro WP, Satria A, Hartoyo H. 2018. The Determinant Factors of Behavior in M-Commerce Application Usage for Online Purchasing. Indonesian Journal of Business and Entrepreneurship (IJBE) 4(2): 118-129. https:// doi.org/10.17358/ijbe.4.2.118. 
Prothero A, Dobscha S, Freund J, Kilbourne WE, Luchs MG, Ozanne LK, Thøgersen J. 2011, Sustainable consumption: opportunities for consumer research and public policy. Journal of Public Policy \& Marketing 30(1): 31-38. https:// doi.org/10.1509/jppm.30.1.31.

Rempel JK, Holmes JG, Zanna MP. 1985. Trust in close relationships. Journal of personality and social psychology 49(1): 95-112. https://doi. org/10.1037/0022-3514.49.1.95.

Schlaegel C. 2015. Understanding individuals' initial and continued use of online auction marketplaces: A meta-analysis. Management Research Review 38(8): 855-907. https://doi.org/10.1108/MRR09-2013-0210.

Shadkam M. 2012. An empirical study on influence factors of online purchasing. International Journal of Arts \& Sciences 5(1): 479-487.

Sun H. 2010. Sellers' trust and continued use of online marketplaces. Journal of the Association for Information Systems 11(4): 183-211. https://doi. org/10.17705/1jais.00226.
Thamizhvanan A, Xavier MJ. 2013. Determinants of customers' online purchase intention: an empirical study in India. Journal of Indian Business Research 5(1): 17-32. https://doi. org/10.1108/17554191311303367.

Veloutsou CA. 2012. Loyalty and or disloyalty to a search engine: the case of young millennials. Journal of Consumer Marketing 29 (2):125-135. https://doi.org/10.1108/07363761211206375.

Venkatesh V, Morris MG, Davis GB, Davis FD. 2003. User acceptance of information technology: Toward a unified view. MIS quarterly 27(3): 425-478. https://doi.org/10.2307/30036540.

Wang LC, Baker J, Wagner JA, Wakefield K. 2007. Can a retail web site be social?. Journal of Marketing 71(3): 143-157. https://doi.org/10.1509/ jmkg.71.3.143.

Yoon SJ. 2002. The antecedents and consequences of trust in online-purchase decisions. Journal of Interactive Marketing 16(2): 47-63. https://doi. org/10.1002/dir.10008. 